\title{
DETERMINATION OF GRANULATED SUGAR ALTERNATIVES USING ANALYTICAL HIERARCHICAL PROCESS (AHP)
}

\author{
Hasan Mastrisiswadi*1, Kurniaji Wahid Solihin², Ardiyanto Azis², Nurul \\ Hidayat Robbiyamto ${ }^{2}$ \\ ${ }^{1}$ Department of Industrial Engineering, UPN “Veteran” Yogyakarta, Jl. Babarsari 2, Tambakbayan, \\ Yogyakarta, 55281 \\ ${ }^{2}$ Department of Industrial Engineering, Universitas Dian Nuswantoro, Jl. Nakula 1 No.5-11, \\ Semarang, 50131
}

(Received: July 12, 2019/ Accepted: February 18, 2020)

\begin{abstract}
In 2019, the government planned to achieve sugar self-sufficiency to meet domestic sugar needs. One type of sugar that is most consumed is granulated sugar. In Indonesia, various models, prices, and sizes of sugar are marketed. Competition for producers in selling their products is getting tighter, so they need to understand the criteria that influence consumers in buying granulated sugar. Research on sugar has been conducted, but until now, research on determining the criteria for sugar products has never been conducted. Many factors are the criteria for choosing sugar to be selected by consumers. To find out what alternatives and criteria are preferred by consumers, the method of Analytical Hierarchical Process (AHP) is used. AHP method consists of several stages that are: hierarchy determination, evaluation of criteria and alternatives, Synthesis of priority, logical consistency, and preference value. From the results of calculations that carried out, it was found that the quality and taste were the highest criteria as a reference for choosing sugar brands.
\end{abstract}

Keywords: AHP; Consumers; Criteria; Granulated Sugar; Quality

\section{Introduction}

Sugar is an essential part of Indonesian society. One type of sugar most consumed by the public is granulated sugar. Granulated sugar is made through a process of separating sucrose in sugarcane stems from other substances (water, organic matter, and coir). This separation process is carried out repeatedly by grinding sugarcane stems to a liquid called sap. The sap can be purified and evaporated so that the liquid becomes more viscous. The next process is crystallization and drying so that the sugar is ready to be packaged and consumed (Macknight \& Kennedy, 2003).

Along with the increase in population, the national sugar consumption in Indonesia rose (Bantacut, 2016; Kurniasari, Darwanto, \& Widodo, 2015; Mardianto, Simatupang, Hadi, Malian, \& Susmiadi, 2017; Sugiyanto, 2007). However, the increase in domestic sugar demand is not balanced with the amount of domestic production. In 2012, there was a deficit of 400,000 tons of sugar, which caused the government to import from abroad (Kurniasari et al., 2015). That's why, in the current era, the new government targeted sugar self-sufficiency in 2019.

\footnotetext{
* Correspondence Author.

E-mail: hasanpahlawan@gmail.com
}

Unfortunately, the prolonged dry season during 2019 in Indonesia has made sugar production not met the target. It is even expected to decline in 2020, so the government is planning to import sugar in this year. In order for domestic sugar products to compete with imported sugar, further research is needed on the preferences of Indonesian consumers towards sugar purchasing decisions.

Research on sugar has been done, but until now, research on determining the criteria for sugar products has never been conducted (Irawan \& Winiarti, 2015; Mardianto et al., 2017; Sukarmen, Sularso, \& Wulandari, 2013). Many factors become the criteria for choosing sugar by consumers.

This study aims to determine what criteria are the most important considerations for consumers in buying granulated sugar products so that producers can use them in marketing their products. To be able to achieve these objectives, this study will use the AHP method. This method can solve multi-object and multicriteria problems based on the comparison of preferences of each element studied. It has been used successfully by many researchers to analyze decision making (Hartini, Nurmalasari, \& Rinawati, 2016; Haryanto, 2016; Izzhati, Mastrisiswadi, \& Talitha, 2017; Makkasau, 2012; Thomas L Saaty \& Sagir, 2015; 
Sari, Yuniaristanto, \& Sutopo, 2016; Viarani \& Zadry, 2016; Yusof \& Hasliah, 2013).

\section{Methods}

This study uses the AHP method, which is one of the models for decision making. There are several stages in the AHP method that are: hierarchy determination, evaluation of criteria and alternatives, Synthesis of priority, logical consistency, and preference value.

\section{a. Hierarchy determination}

The making of a hierarchy is conducted by setting goals first, then broken down into several supporting elements and arranged in the form of a hierarchy. This hierarchy is consisting of criteria and alternatives that will be compared in pairs. The making of this hierarchy is the first step in AHP as a basis for determining preferences to be made.

\section{b. Matrix of Comparison between Criteria and Alternatives}

The next stage in this method is to assess the importance of the criteria and alternatives. The assessment can use a pairwise comparison rating scale table (

Table 1) developed by Saaty (2002).

Table 1. Pairwise Comparative Assessment Scale (T. L. Saaty, 2002)

\begin{tabular}{cl}
$\begin{array}{c}\text { Level of } \\
\text { Importance }\end{array}$ & \multicolumn{1}{c}{ Definition } \\
\hline 1 & These two elements are very important \\
3 & One element is slightly more important than the other elements \\
5 & One element is essential or very important compared to other elements \\
7 & One element is really more important than the other \\
9 & One element is absolutely more important than the other elements \\
$2,4,6,8$ & The middle value between two consecutive assessments \\
\hline
\end{tabular}

\section{c. Synthesis of priority}

After selecting the criteria and alternatives, the next step is to determine priority. The relative comparison values of all criteria and alternatives are adjusted to the judgment that has been determined to produce weights and priorities.

\section{d. Logical consistency}

The next step is to determine the level of consistency. This is done because, in decision making, it is necessary to know how good the consistency is.

\section{e. Preference value}

The final stage in this research is to determine the preference value for each criterion and alternative. It was conducted to answer the purpose of this study

\section{Result and analysis}

a. The hierarchical structure of sugar brand selection Before calculating pairwise comparisons, the hierarchical structure of the problem must first be compiled by defining the problem and determining the desired solution or alternatives. For the selection of brands of sugar, there are five criteria for assessment, that are quality, taste, price, color, and hardness. With three alternative brands, namely "A", "B", and "C". Determination of each criterion and alternatives is obtained through focus group discussions. After that, the hierarchical structure is made, which can be seen in Figure 1.

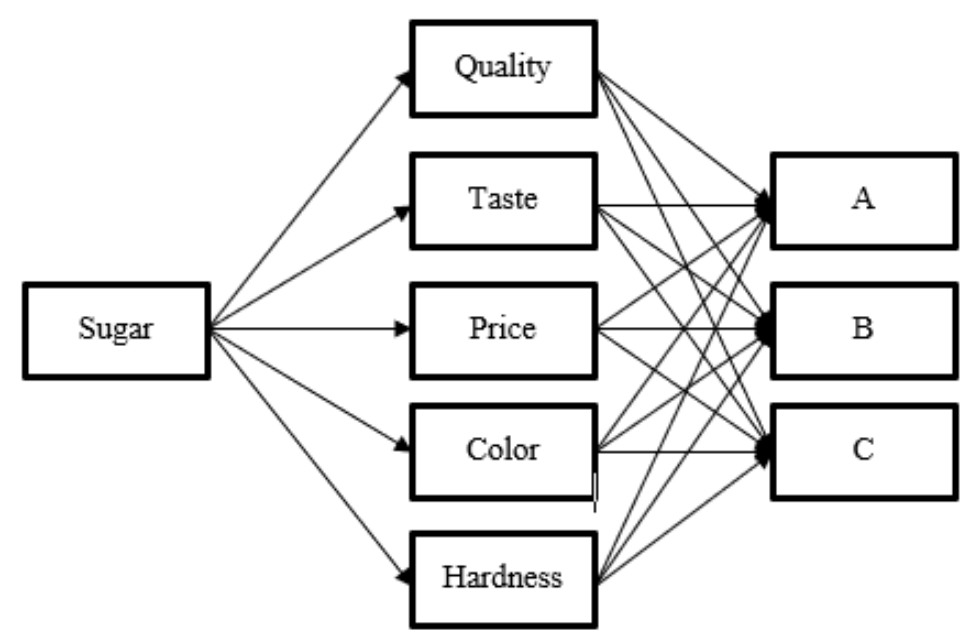

Figure 1. The Hierarchical Structure of Alternative Brand Selection for Sugar 
Table 2. Criteria Comparison Matrix

\begin{tabular}{lccccc}
\hline Criteria & Quality & Taste & Price & Color & Hardness \\
\hline Quality & 1 & 3 & 5 & 2 & 3 \\
Taste & 0,33 & 1 & 2 & 3 & 5 \\
Price & 0,2 & 0,5 & 1 & 2 & 2 \\
Color & 0,5 & 0,33 & 0,5 & 1 & 2 \\
Hardness & 0,33 & 0,20 & 0,5 & 0,50 & 1 \\
Total & 2,36 & 5 & 9 & 9 & 12 \\
\hline
\end{tabular}

Table 3. Brand Comparison Matrix For Each Criterion

\begin{tabular}{cccc}
\hline Quality & $\mathrm{A}$ & $\mathrm{B}$ & $\mathrm{C}$ \\
\hline $\mathrm{A}$ & 1 & 3 & 7 \\
$\mathrm{~B}$ & 0.33 & 1 & 5 \\
$\mathrm{C}$ & 0.14 & 0.2 & 1 \\
Total & 1.48 & 4.2 & 13 \\
\hline Taste & $\mathrm{A}$ & $\mathrm{B}$ & $\mathrm{C}$ \\
\hline $\mathrm{A}$ & 1 & 2 & 7 \\
$\mathrm{~B}$ & 0.5 & 1 & 2 \\
$\mathrm{C}$ & 0.14 & 0.5 & 1 \\
Total & 1.64 & 3.5 & 10 \\
\hline Price & $\mathrm{A}$ & $\mathrm{B}$ & $\mathrm{C}$ \\
\hline $\mathrm{A}$ & 1 & 3 & 5 \\
$\mathrm{~B}$ & 0.33 & 1 & 4 \\
C & 0.2 & 0.25 & 1 \\
Total & 1.53 & 4.25 & 10 \\
\hline Color & $\mathrm{A}$ & $\mathrm{B}$ & $\mathrm{C}$ \\
\hline A & 1 & 4 & 2 \\
B & 0.25 & 1 & 5 \\
C & 0.5 & 0.2 & 1 \\
Total & 1.8 & 5.2 & 8 \\
\hline Hardness & $\mathrm{A}$ & $\mathrm{B}$ & $\mathrm{C}$ \\
\hline A & 1 & 5 & 7 \\
B & 0.2 & 1 & 2 \\
C & 0.14 & 0.5 & 1 \\
Total & 1.34 & 6.5 & 10 \\
\hline & & &
\end{tabular}

Table 4. Normalization Of Criteria Comparison Matrix

\begin{tabular}{lrrrrrr}
\hline Criteria & \multicolumn{1}{c}{ Quality } & \multicolumn{1}{c}{ Taste } & \multicolumn{1}{c}{ Price } & Color & Hardness & TPV \\
\hline Quality & 0.42 & 0.60 & 0.56 & 0.24 & 0.23 & 0.40 \\
Taste & 0.14 & 0.20 & 0.22 & 0.35 & 0.38 & 0.27 \\
Price & 0.08 & 0.10 & 0.11 & 0.24 & 0.15 & 0.14 \\
Color & 0.21 & 0.07 & 0.06 & 0.12 & 0.15 & 0.12 \\
Hardness & 0.14 & 0.04 & 0.06 & 0.06 & 0.08 & 0.08 \\
\hline
\end{tabular}

\section{b. Matrix of Comparison between Criteria and Brands}

The first calculation is to determine the results of the criteria comparison. Error! Reference source not found. shows the result of the pairwise comparison matrix between criteria. After the criteria comparison, the next step is a recapitulation of calculation data between brands with each criterion. Error! Reference source not found. is the granulated sugar brand comparison matrix for each criterion.

, while

Table 5 is the normalization and scoring result of the granulated sugar brand for each criterion. From this table, we can see the value of each total priority

\section{c. Normalization and Scoring}

After a recapitulation of the comparison matrix was carried out, it was continued with normalization and scoring to determine the weight of each criterion and brand. The normalization and scoring calculation result of the granulated sugar criteria can be seen in

value (TPV). TPV is the total priority value obtained by dividing the number of each row by the number of factors. 
Table 5. Normalization Of Brand Comparison Matrix For Each Criterion

\begin{tabular}{ccccc}
\hline Quality & A & B & C & TPV \\
\hline A & 0.68 & 0.71 & 0.54 & 0.64 \\
B & 0.23 & 0.24 & 0.38 & 0.28 \\
C & 0.10 & 0.05 & 0.08 & 0.07 \\
\hline Taste & A & B & C & TPV \\
\hline A & 0.61 & 0.57 & 0.70 & 0.63 \\
B & 0.30 & 0.29 & 0.20 & 0.26 \\
C & 0.09 & 0.14 & 0.10 & 0.11 \\
\hline Price & A & B & C & TPV \\
\hline A & 0.65 & 0.71 & 0.50 & 0.62 \\
B & 0.22 & 0.24 & 0.40 & 0.28 \\
C & 0.13 & 0.06 & 0.10 & 0.10 \\
\hline Color & A & B & C & TPV \\
\hline A & 0.57 & 0.77 & 0.25 & 0.53 \\
B & 0.14 & 0.19 & 0.63 & 0.32 \\
C & 0.29 & 0.04 & 0.13 & 0.15 \\
\hline Hardness & A & B & C & TPV \\
\hline A & 0.74 & 0.77 & 0.70 & 0.74 \\
B & 0.15 & 0.15 & 0.20 & 0.17 \\
C & 0.11 & 0.08 & 0.10 & 0.09 \\
\hline
\end{tabular}

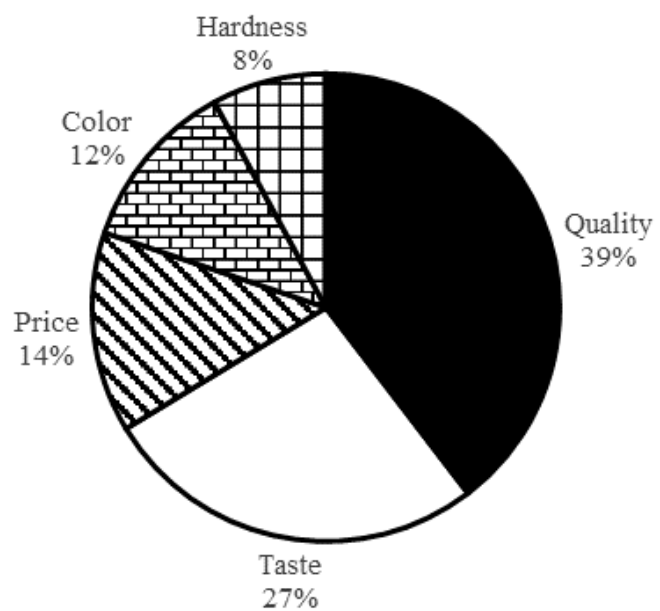

Figure 2. The Comparison Chart Between Criteria

Table 6. Consistency Check

\begin{tabular}{lc}
\hline \multicolumn{1}{c}{ Criteria } & $\lambda$ \\
\hline Quality & 5.9813 \\
Taste & 5.3493 \\
Price & 5.3765 \\
Color & 5.104 \\
Hardness & 5.1968 \\
\hline $\bar{\lambda}$ & 5.4016 \\
\hline $\mathrm{CI}$ & 0.0803 \\
\hline $\mathrm{CR}$ & 0.0717 \\
\hline
\end{tabular}

After normalizing and scoring the criteria comparison matrix, product quality occupies the top level with a TPV value of $40 \%$ as one of the critical criteria that must be owned by granulated sugar products. In the second position with a weight value of $27 \%$ is Taste. The Price is in the third position with a weight value of $14 \%$, and Color is in the fourth position with a value of $12 \%$. The last is the hardness criteria, 
with the smallest value of $8 \%$. The comparison chart between these criteria can be seen in Figure 2.

\section{d. Consistency Check}

The next step is to do a consistency check to determine the level of consistency. In

Table 6, the

Table 7. Preference Value

\begin{tabular}{ccccccc}
\hline \multirow{2}{*}{ Brand } & $\begin{array}{c}\text { Quality } \\
(0.3953)\end{array}$ & $\begin{array}{c}\text { Taste } \\
(0.2663)\end{array}$ & $\begin{array}{c}\text { Price } \\
(0.1394)\end{array}$ & $\begin{array}{c}\text { Color } \\
(0.1235)\end{array}$ & $\begin{array}{c}\text { Hardness } \\
(0.0754)\end{array}$ & Result \\
\hline A & 0.64 & 0.63 & 0.62 & 0.53 & 0.74 & 0.63 \\
B & 0.28 & 0.26 & 0.28 & 0.32 & 0.17 & 0.27 \\
C & 0.07 & 0.11 & 0.1 & 0.15 & 0.09 & 0.1 \\
\hline
\end{tabular}

results of the CR are below 0.1 , with a value of 0.0717 . It means that the results of the calculation of comparisons between criteria and brands have sufficient consistency so that the assessment and processing of data can proceed to the next calculation.

From

Table 6, it can be seen that there is a variable $\lambda$, that can be obtained by dividing the number of rows with the number of elements. Meanwhile, CI is a Consistency index obtained by equation (1), while CR is the consistency ratio obtained by equation (2). The value of $n$ is the number of elements, and RI is the Random consistency Index.

$$
\begin{gathered}
\mathrm{CI}=\frac{(\lambda \text { maks }-n)}{n} \\
\mathrm{CR}=\frac{C I}{R I}
\end{gathered}
$$

From the consistency calculation result in this case study, the results of the lambda value $(\lambda)$ are 5.4016, and the CI value is 0.0803. Meanwhile, the CR value is 0.0717 . Thus, the research result is stated to be consistent and do not need to be re-studied because the $\mathrm{CR}$ value meets the consistency requirements by less than 0.1 .

\section{e. Preference Value}

The last step is to calculate the preference value of each criterion and brand that has been studied to find out the final results of the AHP calculation. Error! Reference source not found. is the final calculation of AHP as a reference for selecting the best-granulated sugar.

The final AHP calculation for granulated sugar products shows that brand " $\mathrm{A}$ " ranks the top of two other brands with a final score of $63 \%$. Brand " $\mathrm{A}$ " is the number one choice of sugar as fulfilling consumer needs. This value has the following details of $64 \%$ for Quality, 63\% for Taste, 62\% for Price, 53\% for Color, and $74 \%$ for Hardness. The second rank is brand " $\mathrm{B}$ ", with a significant difference with brand " $A$ ", which the value is $27 \%$. This value has the following details of $28 \%$ for Quality, 26\% for Taste, 28\% for Price, 32\% for Color, and $17 \%$ for Hardness. The last rank is brand "C", with a weight of $10 \%$. This value has the following details of 7\% for Quality, 11\% for taste, $10 \%$ for Price, $15 \%$ for Color, and $9 \%$ for Hardness.

\section{Conclusion}

Based on the data processing and analysis that has been conducted, it is found that Quality is crucial for consumers in choosing sugar with a weight value of $40 \%$, followed by taste with a value of $27 \%$, and price with a weight value of $14 \%$. Besides, brand "A" occupies the highest position with a weight value of $63 \%$. The second place is the brand "B" with a weight value of $27 \%$ and brand " $\mathrm{C}$ " at the lowest position with a weight value of $10 \%$.

Based on these results, local sugar producers in Indonesia should improve their quality more because it is the factor that most influences consumers in purchasing sugar products. This quality improvement is made so that local sugar products are not inferior to imports. However, this research has not compared the criteria and alternatives of sugar to be imported in 2020. So that further research is needed to examine how consumers' preferences for this imported sugar.

\section{References}

Bantacut, T. (2016). Sugar self-sufficiency: prospects and strategies for achieving it (Swasembada gula: prospek dan strategi pencapaiannya). Jurnal Pangan, 19(3), 245-256.

Hartini, S. H., Nurmalasari, S., \& Rinawati, D. I. (2016). Model of choosing brown color natural dyes for Solo's batik by using Analytical Hierarchy Process (AHP) Method (Model Pemilihan Bahan Pewarna Alam Coklat Batik Tulis Solo Dengan Menggunakan Metode Analytical Hierarchy Process (AHP)). J@TI UNDIP : Jurnal Teknik Industri. doi:10.12777/jati.9.2.77-86

Haryanto, H. (2016). Election of Study Program Chair With AHP Assistance (Pemilihan Ketua Program Studi Dengan Bantuan AHP). J@TI UNDIP : Jurnal Teknik Industri. doi:10.12777/jati.7.1.37-42

Irawan, R., \& Winiarti, S. (2015). Decision Support System for Selection and Evaluation of Product Marketing (Sugar) Location Using Ahp Method (Case Study: Pt. Madubaru) (Sistem Pendukung Keputusan Pemilihan Lokasi Dan Evaluasi Lokasi Pemasaran Produk (Gula) Menggunakan Metode Ahp (Studi Kasus: Pt. Madubaru)). Jurnal Informatika Ahmad Dahlan, 9(2).

Izzhati, D. N., Mastrisiswadi, H., \& Talitha, T. (2017). Analysis on the Selection of Traditional Smoked 
Fish Packaging to Increase Sales Value (Analisis Keputusan Pemilihan Kemasan Ikan Asap Tradisional Untuk Meningkatkan Nilai Penjualan). In Rini Dharmastiti, I. G. B. B. Dharma, M. K. Herliansyah, \& N. A. Masruroh (Eds.), Seminar Nasional Teknik Industri Universitas Gadjah Mada 2017 (pp. 17-21). Yogyakarta: Univ of California Press. Retrieved from

http://web06.opencloud.dssdi.ugm.ac.id/wpcontent/uploads/sites/454/2017/11/BukuProsiding-SeNTI-2017.pdf

Kurniasari, R. I., Darwanto, D. H., \& Widodo, S. (2015). Demand for Indonesian Raw Crystal Sugar (Permintaan Gula Kristal Mentah Indonesia). Ilmu Pertanian (Agricultural Science). doi:10.22146/ipas.6173

Macknight, S. J., \& Kennedy, J. F. (2003). Cane sugar handbook. Carbohydrate Polymers. doi:10.1016/0144-8617(95)90057-8

Makkasau, K. (2012). The Use of Analytic Hierarchy Process (AHP) Method in Determining Priority of Health Programs (Case Study of Health Promotion Programs) (Penggunaan Metode Analytic Hierarchy Process (AHP) Dalam Penentuan Prioritas Program Kesehatan (Studi Kasus Program Promosi Kesehatan)). J@TI UNDIP: Jurnal Teknik Industri. doi:10.12777/jati.7.2.105-112

Mardianto, S., Simatupang, P., Hadi, P. U., Malian, H., \& Susmiadi, A. (2017). Road Map and National Sugar Industry Development Policy (Peta Jalan (Road Map) dan Kebijakan Pengembangan Industri Gula Nasional). Forum Penelitian Agro Ekonomi. doi:10.21082/fae.v23n1.2005.19-37

Saaty, T. L. (2002). Decision making with the Analytic Hierarchy Process. Scientia Iranica. doi:10.1504/ijssci.2008.017590

Saaty, Thomas L, \& Sagir, M. (2015). Choosing the best city of the future. Journal of Urban Management, 4(1), 3-23. doi:10.1016/j.jum.2015.06.003

Sari, A. A., Yuniaristanto, Y., \& Sutopo, W. (2016). Designing a Discount Model Selection System for Pt Abc Textile Product Buyers with AHP Approach (Perancangan Sistem Pemilihan Model Diskon Untuk Buyer Produk Textile Pt Abc Dengan Pendekatan AHP). J@TI UNDIP : Jurnal Teknik Industri. doi:10.12777/jati.8.1.51-58

Sugiyanto, C. (2007). Sugar Demands In Indonesia * (Permintaan Gula Di Indonesia*). Jurnal Ekonomi Pembangunan: Kajian Masalah Ekonomi Dan Pembangunan. doi:10.23917/jep.v8i2.1036

Sukarmen, P., Sularso, A., \& Wulandari, D. (2013). Analysis of Product Innovation on Consumer Satisfaction Effect with Competitive Advantage as an Intervening Variable in Sebelas Sugar Products (Gupalas) of Semboro Ptp Nusantara
Xi (Persero) Sugar Factory (Analisis Pengaruh Inovasi Produk Terhadap Kepuasan Konsumen Dengan Keunggulan Bersaing Sebagai Variabel Intervening Pada Produk Gula Pasir Sebelas (Gupalas) Pabrik Gula Semboro Ptp Nusantara Xi (Persero)). Jurnal Program Studi Magister Manajemen Fakultas Ekonomi Universitas Jember.

Viarani, S. O., \& Zadry, H. R. (2016). Analysis of Supplier Selection with Analitycal Hierarchy Process Method in PT Semen Padang's Indarung VI Project (Analisis Pemilihan Pemasok dengan Metode Analitycal Hierarchy Process di Proyek Indarung VI PT Semen Padang). Jurnal Optimasi Sistem Industri. doi:10.25077/josi.v14.n1.p55-70.2015

Yusof, N. A. M., \& Hasliah, S. (2013). Analytical Hierarchy Process in Multiple Decisions Making for Higher Education in Malaysia. Procedia - Social and Behavioral Sciences, 81, 389-394. doi:10.1016/j.sbspro.2013.06.448 